\title{
METODE TERAPI SUFISTIK DALAM MENGATASI GANGGUAN KEJIWAAN
}

\author{
Oleh : St. Rahmatiah \\ Dosen Jurusan Bimbingan dan Penyuluhan Islam \\ Fakultas Dakwah dan Komunikasi \\ UIN Alauddin Makassar \\ E-mail: sittirahmatiah@uin-alauddin.ac.id
}

\begin{abstract}
Abstrak
Gangguan kejiwaan merupakan sindrom atau pola perilaku, atau psikologik seseorang, yang secara klinik cukup bermakna, dan yang secara khas berkaitan dengan suatu gejala penderitaan (distress) atau hendaya (impairment/disability) di dalam satu atau lebih fungsi yang penting dari manusia. Fenomena yang kita lihat bahwa penyakit yang diderita manusia tidak selamanya dapat disembuhkan dengan obat medis atau kecanggihan perangkat medis. Ketika penyakit jasmani disembuhkan maka yang tampak adalah kesehatan secara fisik. Akan tetapi, jika penyakit psikis disembuhkan yang tampak adalah perilaku-perilaku mental hidup yang sehat. Di sinilah kemudian tasawuf memberikan jawaban untuk menemukan totalitas jasmani dan rohani dalam diri manusia. Karena itu, kaum sufi memperkenalkan pengobatan secara sufistik atau psioterapi sufistik. Terapi sufistik ini yang dimaksudkan adalah pengobatan yang bernuansa islami dengan sasaran untuk mewujudkan manusia yang berjiwa sehat. Pendekatannya dapat dilakukan melalui bimbingan penyuluhan, pendekatan tobat, pendekatan dzikir, dan sebagainya
\end{abstract}

Kata kunci: gangguan kejiwaan, terapi sufistik.

\section{PENDAHULUAN}

Era globalisasi dan modernisasi membawa dampak positif dan negatif dalam kehidupan manusia. Satu sisi perkembangan ini memberi manfaat dalam membantu aktifitas manusia dalam segala di mensi kehidupannya tetapi di sisi lain menimbulkan permasalahan baru seperti de humanisasi masyarakat modern, merenggangnya ikatan-ikatan sosial, dan terabaikannya nilai-nilai spiritual. $^{1}$

Dari problem-problem itulah kemudian muncul suatu stress dan depresi atau gangguan kejiwaan apabila seseorang tidak memiliki daya tahan mental dan spiritual yang tangguh. Keimanan yang lemah sangat rentan dan mudah tertimpa keadaan stress dan depresi. Kekuatan iman dan ketaqwaan pasti akan menghasilkan daya tahan mental yang kokoh dan kuat dalam menghadapi berbagai problem hidup dan kehidupan.

Dengan kondisi seperti itu, barangkali manusia akan mengalami konflik batin secara besarbesaran. Konflik tersebut sebagai dampak dari ketidakseimbangan antara kemampuan iptek yang

\footnotetext{
${ }^{1}$ Ahmad Najib Burhani, Manusia Modern Mendamba Allah, Renungan Tasawuf Positif, (Jakarta : Mizan Media Utama, 2002), h. 166.
} 
mengahasilkan kebudayaan materi dengan kekosongan rohani. Kegoncangan batin yang diperkirakan akan melanda umat manusia ini, barangkali akan memengaruhi kehidupan psikologis manusia. Pada kondisi ini, manusia akan mencari penentram batin, antara lain agama. Hal ini pula barangkali yang menyebabkan munculnya ramalan futurolog bahwa di era globalisasi agama akan memengaruhi jiwa manusia. $^{2}$

Kecanggihan dunia medis sekarang ini tampaknya mulai diiringi oleh perkembangan berbagai pengobatan alternatif yang menjamur di mana-mana. Harus diakui bahwa kehadiran pengobatanpengobatan alternatif ini tidak dapat dinafikan peranannya dalam berpartisipasi menyehatkan masyarakat. Hal ini merupakan fenomena bahwa penyakit yang diderita manusia tidak selamanya dapat disembuhkan dengan obat medis atau kecanggihan perangkat medis. ${ }^{3}$ Ketika penyakit jasmani disembuhkan maka yang tampak adalah kesehatan secara fisik. Akan tetapi, jika penyakit psikis disembuhkan yang tampak adalah perilaku-perilaku mental hidup yang sehat. Di sinilah kemudian tasawuf memberikan jawaban untuk menemukan totalitas jasmani dan rohani dalam diri manusia.

Kaum sufi umumnya memandang bahwa dunia spiritual dapat berimplikasi bagi dunia material. Dengan itu mereka memperkenalkan pengobatan secara sufistik atau psioterapi sufistik. Terapi sufistik ini yang dimaksudkan adalah pengobatan yang bernuansa islami dengan sasaran untuk mewujudkan manusia yang berjiwa sehat. Pendekatannya dapat dilakukan melalui bimbingan penyuluhan, pendekatan tobat, pendekatan dzikir, dan sebagainya. ${ }^{4}$ Fazlurahman dalam bukunya, Health and Medicine in the Islamic Tradition Change and Identity, mengungkapkan bahwa pengobatan spiritual atau terapi sufistik menjadi penting di era modern sekarang ini. Bahkan beberapa ahli kedokteran jiwa meyakini bahwa penyembuhan penyakit pasien atau klien dapat dilakukan cepat jika menggunakan metode-metode yang berdasarkan spiritual keagamaan, yaitu dengan membangkitkan potensi keimanan kepada Tuhan, lalu menggerakkannya ke arah pencerahan batinnya atau pencerahan spiritual yang pada hakikatnya menimbulkan kepercayaan diri bahwa Tuhan Yang Maha Esa adalah satu-satunya kekuatan penyembuhan penyakit yang diderita. ${ }^{5}$ Tasawuf di sini sebagai salah satu alternatif pengobatan terhadap jiwa-jiwa yang sakit serta kering dari nilai nilai spiritual.

\section{PEMBAHASAN}

\section{A. Faktor Penyebab Gangguan Kejiwaan}

\footnotetext{
${ }^{2}$ Jalaluddin, Psikologi Agama, Edisi Revisi, (Jakarta : PT. Raja Grafindo Persada, 2000), h. 197.

${ }^{3}$ M. Solihin, Penyembuhan Penyakit kejiwaan Perspektif Tasawuf (Bandung: Pustaka Setia, 2004), 9.

${ }^{4}$ M. Solihin, Penyembuhan Penyakit kejiwaan Perspektif Tasawuf, h. 12.

${ }^{5}$ Gusti Abdurrahman, Terapi Sufistik untuk Penyembuhan Gangguan Kejiwaan (Yogyakarta: AswajaPressindo, 2010), 5.
} 


\section{Konsep Gangguan Kejiwaan}

Gangguan kejiwaan merupakan sindrom atau pola perilaku, atau psikologik seseorang, yang secara klinik cukup bermakna, dan yang secara khas berkaitan dengan suatu gejala penderitaan (distress) atau hendaya (impairment/disability) di dalam satu atau lebih fungsi yang penting dari manusia. Sebagai tambahan, disimpulkan bahwa disfungsi itu adalah disfungsi dalam segi perilaku, psikologik, atau biologik, dan gangguan itu tidak semata-mata terletak di dalam hubungan antara orang itu dengan masyarakat. ${ }^{6}$

Salah satu definisi gangguan jiwa menurut Frederick H. Kanfer dan Arnold P. Goldstein, yaitu kesulitan yang harus dihadapi oleh seseorang karena hubungannya dengan orang lain, kesulitan karena persepsinya tentang kehidupan dan sikapnya terhadap diri sendiri. ${ }^{7}$

Adapun definisi gangguan jiwa menurut konsep pedoman penggolongan dan diagnostik gangguan jiwa (PPDGJ-III) adalah bahwa :

Gangguan jiwa merupakaan sindrom atau pola perilaku, atau psikopatologi seseorang yang secara klinik cukup bermakna, dan yang secara khas berkaitan dengan satu gejala penderitaan (Distress) atau impairmen/distability didalam satu atau lebih fungsi yang penting dari manusia. Sebagai tambahan disimpulkan bahwa disfungsi itu adalah disfungsi dalam segi perilaku, atau biologi, dan gangguan-gangguan itu tidak semata-mata terletak dalam hubungan antara orang itu dengan masyarakat. ${ }^{8}$

Sedangkan yang dimaksud "disability" adalah keterbatasan atau kekurangan kemampuan untuk melaksanakan suatu aktifitas pada tingkat personal, yaitu melakukan kegiatan kehidupan seharihari yang biasa dan diperlukan untuk perawatan diri dan kelangsungan hidup (mandi, makan, kebersihan diri, buang air besar dan kecil). ${ }^{9}$

a. Gejala Umum Gangguan Psikosis :

1) Ada kepecahan pribadi, dan kekalutan mental yang progresif, juga terdapat disorientasi terhadap lingkungan, sehingga reaksinya terhadap stimulus ekstern dan konflik batin sendiri selalu salah, dan berbentuk ganguan afektif yang parah (gangguan perasaan atau emosional).

2) Hubungan dengan dunia realitas jadi terputus. Tidak ada insting atau wawasan. Biasanya pasien tidak menyadari gejala dan penyakitnya. Responnya terhadap sekitar selalu tidak tetap atau keliru, penderita suka tertawa-tawa, mengikik-ngikik terus- menerus.

3) Ada maladjustment disertai disorganisasi dari fungsi-fungsi pengenalan, kwajiban, inteligensi, perasaan dan kemauan.

\footnotetext{
${ }^{6}$ Rusdi Maslim, PPDGJ-III (Jakarta: PT. Nuh Jaya, 2001), h. 7.

${ }^{7}$ Djamaludin Ancok, Psikologi Islam (Yogyakarta, Pustaka Pelajar, 2001), 91.

${ }^{8}$ Rusdi Maslim, PPDGJ-III , h. 7

${ }^{9}$ Kartini Kartono, Hygiene Mental, (Bandung: Mandar Maju, 2000), h. 128
} 
4) Sering kali dibayangi oleh halusinasi, ilusi dan delusi. Selalu merasa takut dan bingung, khususnya ada kekacauan emosional yang kronis.

5) Sering mengalami stupor. Jika pasien menjadi agresif, sifatnya jadi kasar, keras kepala dan kurang ajar. Bahkan menjadi eksplosif meledak-ledak, ribut, berlari-lari dan amat berbahaya. Ia mungkin menyerang dan membunuh orang lain, atau membunuh dirinya sendiri. ${ }^{10}$

b. Tingkah laku Umum Gangguan Psikosis :

1) Seluruh kepribadian terpengaruh tidak ada kontak dengan realitas.

2) Menetap dan makin lama makin buruk, pada umumnya tidak mampu melakukan partisipasi sosial, sering kali ada gangguan dalam bicara.

3) Kehilangan orientasi terhadap lingkungan.

4) Tidak dapat memahami tingkah-lakunya sendiri.

5) Tingkahlaku membahayakan diri sendiri dan orang lain,

6) Penderita sukar diatur. ${ }^{11}$

Sedangkan ciri-ciri orang yang mengalami gangguan jiwa menurut Kanfer dan Goldstein adalah sebagai berikut:

a. Hadirnya perasaan cemas (anxiety) dan perasaan tegang (tension) di dalam diri.

b. Merasa tidak puas (dalam artian negative) terhadap perilaku diri sendiri.

c. Perhatian yang berlebihan terhadap problem yang dihadapinya.

d. Ketidakmampuan untuk berfungsi secara efektif di dalam menghadapi problem. ${ }^{12}$

Dari ciri-ciri tersebut tidak dirasakan oleh penderita, namun ciri-ciri tersebut dirasa oleh masyarakat yang ada di sekitarnya. Hal itu kadang dirasa merugikan masyarakat bahkan dapat juga merugikan diri penderita sendiri.

\section{Faktor Penyebab Gangguan Kejiwaan}

Penyebab gangguan kejiwaan terdapat pada satu atau lebih dari ketiga bidang yaitu badaniah, psikologik dan sosial yang terus menerus saling memengaruhi, karena manusia bereaksi secara holistic, maka terdapat kecenderungan untuk membuat diagnosa multidimential yang berusaha mencakup ketiga bidang ini. Ketiga bidang tersebut adalah:

a) Bidang badaniah, setiap faktor yang mengganggu perkembangan fisik dapat mengganggu perkembangan mental. Faktor-faktor ini mungkin dari keturunan atau dari lingkungan.

\footnotetext{
${ }^{10}$ Kartini Kartono, Hygiene Mental, (Bandung: Mandar Maju, 2000), h. 129.

${ }^{11}$ Sarwono Sarlito Wirawan, Pengantar Umum Psikologi, (Jakarta: Bulan Bintang, 1996), h. 119.

${ }^{12}$ Djamaludin Ancok, Psikologi Islam (Yogyakarta, Pustaka Pelajar, 2001), 91.
} 
b) Bidang psikologik, perkembangan psikologik yang salah mungkin disebabkan oleh berbagai jenis deprivasi dini, pola keluarga yang patogenik dan masa remaja yang dilalui secara tidak baik.

c) Bidang sisiologik pun tidak kecil peranannya dalam perkembangan yang salah, misalnya adat istiadat dan kebudayaan yang kaku ataupun perubahan-perubahan yang cepat dalam dunia modern ini, sehingga menimbulkan stres yang besar pada individu. ${ }^{13}$

Dari pengalaman para ahli jiwa dengan pasien-pasiennya yang menderita kesukaran-kesukaran emosi dan gangguan jiwa, serta hasil-hasil penyelidikan ilmiah yang dilakukan oleh tingkah-laku dan sikap seseorang, terbukti bahwa gangguan jiwa terjadi antara lain akibat dorongan untuk memenuhi keinginan-keinginan atau kebutuhan-kebutuhan itu tidak terpenuhi orang akan merasakaan tidak enak, gelisah dan kecewa. Untuk menghilangkan rasa yang tidak enak itulah kebutuhan-kebutuhan itu harus dipenuhi, sebab selama kebutuhan tersebut belum terpenuhi, kegelisahan itu akan tetap terasa, yang akan menimbulkan gangguan kejiwaan. ${ }^{14}$

Adapun faktor-faktor yang menyebabkan timbulnya ganguan kejiwaan psikosis adalah :

a) Konstitusi pembawaan mental dan jasmaniah yang herediter, yaitu diwarisi dari orang tua atau generasi sebelumnya yang psikosis.

b) Kebiasaan-kebiasaan yang buruk, dan mengembangkan pola-pola kebiasaan yang salah sejak masa kanak-kanak. Ditambah dengan maladjustment parah, dan menggunakan escape mechanism dan defence mechanism yang negatif, sehingga internal yang serius dan lambat laun terjadi disintegrasi kepribadian. $^{15}$

Faktor penyebab timbulnya gangguan psikosis lainnya :

a) Predisposisi struktur biologis atau jasmani dan mental atau struktur kepribadian yang lemah (pengaruh internal).

b) Konflik sosial dan konflik kultural (pengaruh-pengaruh eksternal) yang mempengaruhi pribadi, dan mengubah tingkah laku menjadi abnormal.

c) Pemasakan batin dari pengalaman (pencernaan pengalaman, dalam diri subyek) dengan cara yang salah. Jadi ada proses intrapsikis yang salah. ${ }^{16}$

Sebab yang lain karena, keracunan akibat minuman keras, obat-obatan atau narkotika, akibat penyakit yang kotor (sipilis, gonorhoe), dan lain-lain, sehingga terjadi kerusakan pada anggota tubuh,

\footnotetext{
${ }^{13}$ M. Solihin, Terapi Sufistik; Penyembuhan Penyakit Kejiwaan Perspektif Tasawuf (Bandung: Pustaka Setia, 2004), 44.

${ }^{14}$ Zakiah Daradjat, Peranan Agama dalam Kesehatan, (Jakarta : Gunung Agung, 1982), h.32

${ }^{15}$ Kartini Kartono, Hygiene Mental, (Bandung : Mandar Maju, 2000), h. 130.

${ }^{16}$ Kartini Kartono, Psikologi Abnormal dan Abnormalitas Seksual, (Bandung: Mandar Maju, 1989), h. 195.
} 
seperti otak, sentral syaraf atau kehilangan kemampuan berbagai kelenjar, syaraf-syaraf atau anggota fisik lainnya untuk menjalankan tugasnya.

\section{B. Metode Terapi Sufistik dalam Mengatasi Gangguan Kejiwaaan}

Penyembuhan sufi merupakan sebuah tren baru di kalangan masyarakat modern yang tampaknya telah mengalami titik jenuh dengan berbagai pola orientasi material. Sebagian mereka mulai melirik dunia spiritual dalam bermacam-macam lini kehidupan, termasuk dunia kesehatan. Setelah sistem pengobatan medis dalam arti pengobatan dengan alat-alat canggih dan bahan-bahan kimia berkembang sedemikian rupa, namun pada kenyataannya tidak mampu menyelesaikan secara utuh persoalan-persoalan penyakit yang banyak diderita, maka orang kemudian beralih ke pengobatan yang bersifat alternatif spiritualistik. Kecenderungan ini terus berkembang mengikuti tren sufistik.

\section{Konsep Terapi Sufistik}

Terapi adalah upaya pengobatan yang ditujukan untuk penyembuhan kondisi psikologis. ${ }^{17}$ Terapi dalam bahasa Inggris bermakna pengobatan dan penyembuhan, sedangkan dalam bahasa Arab, kata ini sepadan dengan شفى - يثفى - شفاء yang berasal الا ستثفاء yang mempunyai makna penyembuhan, seperti terdapat dalam firman Allah swt. yang memuat kata "syifa": dalam QS. Yunus/10: 57.

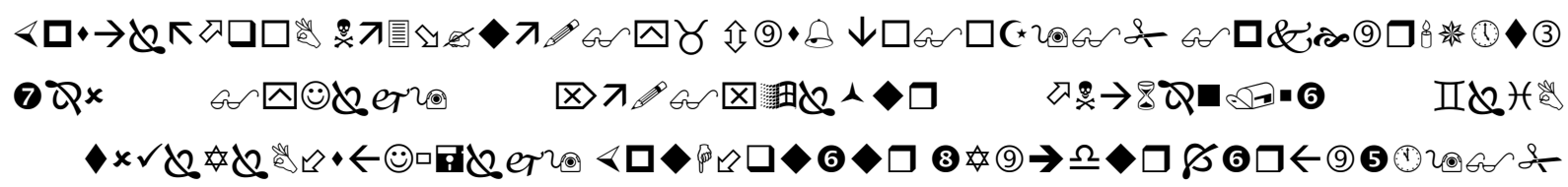

Terjemahnya:

Hai manusia, Sesungguhnya telah datang kepadamu pelajaran dari Tuhanmu dan penyembuh bagi penyakit-penyakit (yang berada) dalam dada dan petunjuk serta rahmat bagi orang-orang yang beriman. ${ }^{18}$

Ayat ini menegaskan bahwa al-Qur'an adalah obat bagi apa yang terdapat dalam dada. Penyebutan kata dada yang diartikan dengan hati, menunjukkan bahwa wahyu-wahyu Ilahi itu berfungsi menyembuhkan penyakit-penyakit ruhani. Memang oleh al-Qur'an hati ditunjuknya sebagai wadah yang menampung rasa cinta dan benci, berkehendak dan menolak, bahkan hati dinilai sebagai alat untuk mengetahui. Hati juga mampu melahirkan ketenangan dan kegelisahan serta menampung sifat-sifat baik dan terpuji.

Thahir Ibnu Asyur mengemukakan bahwa ayat itu memberi perumpamaan tentang jiwa manusia dalam kaitannya dengan kehadiran al-Qur'an sebagai rahmat. Orang yang sakit adalah yang tidak stabil kondisinya, timpang keadaannya lagi lemah tubuhnya. ${ }^{19}$

\footnotetext{
${ }^{17}$ J. P. Chaplin, Kamus Lengkap Psikologi (Jakarta: PT. Raja Grafindo Persada, 1999), 507.

${ }^{18}$ Kementerian Agama RI, Al-Qur'an dan Terjemahnya (DKU print, 2015)., h. 215.

${ }^{19}$ Quraish Shihab, Tafsir Al-Mishbah, Volume: 6 (Jakarta: Lentera Hati, 2002). h. 103.
} 
Ayat di atas menunjukkan bahwa agama itu sendiri berisikan aspek terapi bagi gangguan jiwa. Namun bagaimanakah pelaksanaan dari proses terapi tersebut haruslah dilihat dari ajaran-ajaran Islam itu sendiri. Kebenaran al-Qur'an dipaparkan bahkan dibentangkan dihadapan semua manusia. Ayat ini menyampaikan fungsi wahyu: Hai seluruh manusia, dimana dan kapanpun sepanjang masa, sadarilah bahwa sesungguhnya telah datang kepada kamu semua pengajaran yang sangat agung dan bermanfaat dari Tuhan Pemeliharaan dan Pembimbing yaitu al-Qur'an al-Karim dan obat yang sangat ampuh bagi penyakit-penyakit kejiwaan yang terdapat dalam dada yakni hati manusia dan petunjuk yang sangat jelas menuju kebenaran dan kebajikan serta rahmat yang amat besar lagi melimpah bagi orang-orang mukmin.

Ketika menafsirkan QS. Yunus/10: 57, Quraish Shihab mengemukakan bahwa sementara ulama memahami bahwa-ayat-ayat al-Qur'an dapat juga menyembuhkan penyakit-penyakit jasmani. Mereka merujuk kepada sekian riwayat yang diperselisihkan nilai dan maknanya, antara lain riwayat oleh Ibn Mardawaih melalui sahabat Nabi saw. bersabda: "Hendaklah engkau membaca al-Qur'an." Riwayat dengan makna serupa dikemukakan juga oleh al-Baihaqi melalui Wai'lah Ibn al-Ashqa'. Sufi besar al-Hasan al-Bashri sebagaimana dikutip oleh Muhammad Sayyid Thanthawi dan berdasarkan riwayat Abu asySyeikh berkata: “Allah swt. menjadikan al-Qur'an sebagai obat terhadap penyakitpenyakit hati dan tidak menjadikannya untuk penyakit jasamani. ${ }^{20}$

Tanpa mengurangi penghormatan terhadap al-Qur'an dan hadist-hadist Nabi saw., agaknya riwayat ini bila benar, maka yang dimaksud bukanlah penyakit jasmani, tetapi ia adalah penyakit ruhani / jiwa yang berdampak pada jasmani yang disebut psikosomatik. Memang tidak jarang seseorang merasa sesak nafas atau dada bagaikan tertekan karena adanya ketidakseimbangan ruhani.

Thabathaba'i memahami fungsi al-Qur'an sebagai obat dalam arti menghilangkan dengan bukti-bukti yang dipaparkannya aneka keraguan/syubhat serta dalih yang boleh jadi hinggap dihati sementara orang. Hanya saja ulama menggaris bawahi bahwa penyakit-penyakit tersebut berbeda dengan kemunafikan atau kekufuran. Penyakit-penyakit kejiwaan adalah keraguan dan kebimbangan batin yang dapat hinggap di hati orang-orang beriman. Mereka tidak wajar dinamai munafik apalagi kafir, tetapi tingkat keimanan mereka masih rendah.

Tidak diragukan lagi bahwa nilai-nilai ruhani memiliki peranan besar dalam menerapi jiwa. Kata syifa' biasa diartikan kesembuhan atau obat, dan digunakan juga dalam arti keterbatasan dari kekurangan, atau ketiadaan aral dalam memperoleh manfaat. ${ }^{21}$

Juga kata-kata "Syifa"" atau "Istisyfa" mengandung beberapa makna seperti:

\footnotetext{
${ }^{20}$ Quraish Shihab, Tafsir Al-Mishbah, Volume: 7., h. 532.

${ }^{21}$ Quraish Shihab, Tafsir Al-Mishbah, Volume: 7., h. 533.
} 
Ahsana, artinya mengadakan perbaikan, Ashlaha, artinya melakukan perbaikan, Zakkaa, artinya mensucikan, membersihkan dan memperbaiki, Thahhara, artinya mensucikan dan membersihkan., Akhraja, artinya mengeluarkan, mengusir, membuang atau meniadakan., Syaraha, artinya menjelaskan, membuka, meluaskan dan melapangkan., Wadha'a'an, artinya hilangkan, cabutkan dan menurunkan., Ghafara, artinya menutupi, mengampuni, memperbaiki., Kaffara, artinya menyelubungi, menutupi, mengampuni dan menghapuskan, Naza'a, artinya mencabut, memecat, melepaskan dan menjauhkan. ${ }^{22}$

Setelah kita mengerti mksud hati atau dada ini, dapatlah kita fahami tujuan al-Quran yang kedua, yakni bahwa al-Qur'an mengandung satu obat bagi apa yang ada dalam dada sebab penyakit hati kalau tidak segera diobati akan menjadi peyakit rohani dan jasmani, tubuh halus dan tubuh kasar. Sakit hati memengaruhi sehingga badan menjadi sakit, jiwa sakit berlarut-larut sehingga segalanya sakit, maka dalam ayat ini, Tuhan bersabda: bahwa unsur kedua dari al-Qur'an, selain berisi pengajaran adalah berisi suatu obat bagi yang dalam dada. ${ }^{23}$

Oleh karena itu, terapi sufistik adalah pengobatan dan penyembuhan terhadap penyakit fisik, mental, atau kejiwaan, rohani atau spiritual dengan kerangka pemikiran tasawuf. ${ }^{24}$ Terapi sufistik menyajikan sebuah gambaran yang berbeda tentang manusia dan kehidupannya. Berdasarkan pada visi yang sangat luas mengenai siapa dan apa manusia yang tidak terbatas pada sesuatu yang tampak saja dalam diri manusia, tetapi mencakup yang lebih luhur, lebih lembut dan tingkat-tingkat yang lebih kasat mata melampaui dunia fisik.

Terapi sufistik (ath-thibb ash-shufi) bukan sekedar teori, tetapi juga bersifat praktis. Para sufi telah membuat rumusan tata cara menerapi penyakit jiwa bagi para pasien mereka, yaitu dengan cara menjelaskan kepada para pasien tersebut jalan menuju kesempurnaan jiwa dengan membangkitkan ruh keimanan dalam jiwa lemah, mengajak mereka untuk membersihkan hati/niat, memperkuat tekad, menyerahkan segala urusan kepada Allah swt. dan taqwa kepada-Nya, dan dianjurkan mereka untuk memenuhi jiwa dengan kejujuran, hati dengan ikhlasan, dan perut dengan barang-barang yang halal. Kemudian mengajak mereka untuk menerapi jiwa-jiwa yang resah melalui dzikir yang benar, yang dapat menentramkan jiwa yang lemah dan depresi. ${ }^{25}$

\footnotetext{
${ }^{22}$ Quraish Shihab, Tafsir Al-Mishbah, Volume: 7., h. 533.

${ }^{23}$ Hamdani Bakran Adz-Dzaky, Konseling dan Psikoterapi Islam, (Yogyakarta: Fajar Pustaka Baru, 2002), h. $231-236$

${ }^{24}$ Gusti Abdurrahman, Terapi Sufistik untuk Penyembuhan Gangguan Kejiwaan (Yogyakarta: AswajaPressindo, 2010), 5.

${ }^{25}$ Amir An-Najar, Psikoterapi Sufistik dalam Kehidupan Modern. ter. Ija Suntana (Jakarta: Mizan Publika, 2004), 180.
} 
Orang yang sedang mengalami gangguan jiwa, apalagi sampai mengalami gangguan Psikosis ${ }^{26}$ sudah sewajarnya untuk kembali kepada ajaran Islam. Terapi sufistik dengan menggunakan dasar pijakan dari nilai-nilai dan ajaran agama Islam, tidak hanya ditujukan untuk mengobati penyakit kejiwaan dalam kriteria mental psikologis-sosial, tetapi juga memberikan terapi kepada orang-orang yang "sakit" secara moral dan spiritual. Dengan demikian, terapi sufistik dengan cakupan yang lebih luas dapat mengantisipasi dan mengobati masalah gangguan jiwa manusia, baik dalam segi kejiwaan itu sendiri maupun segi moral-spiritual.

Bagi kaum sufi, penyembuhan tasawuf telah dilakukan sejak mereka memasuki tahap alBidayah (permulaan), yaitu memasuki beberapa tahap kesufian, yakni takhalli (pengosongan jiwa dari segala sesuatu yang mulia), tahalli (pengisian jiwa dengan ketaatan), tajalli (menemukan apa yang dicari dan meng-aplikasikannya dalam kehidupan sehari-hari). Kemudian mujahadah dan riyadhah, melalui maqamat dan ahwal. Lalu sampailah pada nihayah (akhir pencarian). Para sufi menamai nihayah ini sebagai maqam terakhir, yaitu wushul (pencapaian), ihsan (perbuatan yang baik), atau fana' (ketidak kekalan). Orang yang telah sampai pada manzilah ini dinamakan ahl al-Irfan. Namun bagi orang awam, banyak jalan yang bisa ditempuh untuk melakukan terapi sufistik. Jalan-jalan tersebut antara lain sama dengan apa yang dilakukan oleh kaum sufi, yakni dengan melalui cara berdzikir, shalat, membaca sholawat, dan mendengarkan musik. ${ }^{27}$ Cara-cara ini terbukti sangat ampuh dalam mengatasi berbagai penyakit. Tentu saja, dengan metode atau kaifiyah tertentu atau dengan bimbingan seorang guru. Namun di sini penulis membatasi diri hanya beberapa metode terapi yang penulis sebutkan yaitu metode pertaubatan, metode dzikir, membaca al-Qur'an, doa, shalat dan zakat.

\section{Metode-Metode Terapi Sufistik}

a). Melakukan Pertaubatan

Istilah taubat secara bahasa berarti kembali, yaitu kembali dari berbuat dosa dan maksiat menuju berbuat baik dan ketaatan, sesudah menyadari keburukan dan bahaya perbuatan dosa dan maksiat. Adapun taubat menurut ajaran Islam adalah meninggalkan perbuatan dosa dan maksiat karena

\footnotetext{
${ }^{26}$ Psikosafungsional atau psikosis ialah merupakan penyakit/gangguan mental yang parah, yang ditandai oleh disorientsi fikiran, gangguan-gangguan emosional, disorientasi waktu dan ruang, serta pribadi dan pada beberapa kasus disertai halusinasi dan delusi-delusi. Dan orang tersebut tidak dapat lagi hidup dan bergaul normal dengan orang lain disekitarnya. Psikosis merupakan penyakit mental secara fungsional yang berat dan non organis sifatnya, ditandai oleh disintregrasi (kepecahan kepribadian) dan maladjustment social yang berat: orangnya tidak mampu mengadakan relasi sosial dengan dunia luar, sering terputus sama sekali dengan realitas hidup, lalu menjadi inkompeten secara sosial. Terdapat pula gangguan pada karakter dan fungsi intelektualnya. Lihat; Kartini Kartono, Hygiene Mental, h. 128.
}

${ }^{27}$ M. Amin Syukur, Sufi Healing; Terapi dengan Metode Tasawuf (Jakarta: Erlangga, 2012), 72. 
menyesali, kemudian tidak berniat untuk mengulanginya lagi. ${ }^{28}$ Jika istilah taubat dalam bahasa Arab adalah kembali, berarti taubat kepada Allah artinya kembali kepada-Nya dan berdiri di ambang pintuNya. Sebab yang paling mendasar bagi manusia adalah kedekatan dengan Allah dan menyambung tali penghambaan kepada-Nya, tidak menjauh dari-Nya, senantiasa membutuhkan-Nya dalam kehidupan fisik dan psikisnya.

Taubat yang sesungguhnya berpangkal pada pengertian dan kesadaran bahwa seseorang telah terlanjur mengerjakan kesalahan yang akibatnya merusak dirinya sendiri, baik di dunia maupun di akhirat. Ia menyadari bahwa melanggar larangan Tuhan atau melalaikan apa yang diwajibkan Tuhan adalah dosa dan karenanya ia akan menerima siksaan. Oleh karena itu, timbul penyesalan dalam hatinya dan ia berniat tidak akan mengulanginya lagi. Jadi, taubat artinya penyesalan atas sifat dan sikap buruk yang kita punyai dan amalkan.

Taubat dapat membantu seseorang melepaskan diri dari kegelisahan dan kegoncangan jiwa yang dapat memengaruhi kesehatannya. Di dalam pertobatan terdapat perubahan sikap yang terjadi pada aspek kognitif, afektif, dan psikomotor. ${ }^{29}$ Metode terapi taubat dengan mencari perilaku buruk yang menjadi penyebab penyakit dengan melakukan mujahadah dan riyadhah, menjauhi orang-orang yang biasa mendorong untuk berbuat maksiat, selanjutnya menjalankan ajaran-ajaran agama yang dulu telah ditinggalkan kemudian banyak berdzikir.

Proses terapi terhadap gangguan kejiwaan atau ruhaniyah yang menggunakan tazkiyah nafsiyah (penyucian jiwa) dengan taubat adalah sebuah metode yang hanya dapat dilakukan oleh seorang terapis yang telah memahami, mengamalkan dan mengalami pertaubatan dengan baik dan benar serta telah memiliki kemampuan dalam menggunakan metode propetik. Jika tidak maka pengawasan dan evaluasi terhadap perkembangan dari esensi pertaubatan itu tidak dapat diketahui secara tepat dan benar, karena dosa mengakibatkan orang menjadi stres maka perlu untuk bertaubat. ${ }^{30}$ b. Dzikir

Dzikir dalam arti sempit memiliki makna menyebut asma-asma Allah Yang Agung dalam berbagai kesempatan. Sedang dalam arti luas, dzikir mencakup pengertian "mengingat segala keagungan dan kasih sayang Allah swt., yang telah diberikan kepada kita, sambil mentaati segala

\footnotetext{
${ }^{28}$ M. Solihin, Terapi Sufistik; Penyembuhan Penyakit Kejiwaan Perspektif Tasawuf (Bandung: Pustaka Setia, 2004), 123.

${ }^{29}$ M. Solihin, Terapi Sufistik; Penyembuhan Penyakit Kejiwaan Perspektif Tasawuf, 127.

${ }^{30}$ M. Solihin, Terapi Sufistik; Penyembuhan Penyakit Kejiwaan Perspektif Tasawuf., h. 128.
} 
perintah-Nya dan menjauhi larangan-Nya. Menurut Al- Ashfahani, dzikir adalah menghadirkan sesuatu baik dalam bentuk perasaan (hati) maupun perbuatan. ${ }^{31}$

Dzikir dapat mengembalikan kesadaran seseorang yang hilang, sebab aktivitas dzikir mendorong seseorang untuk mengingat, menyebut dan mereduksi kembali hal-hal yang tersembunyi dalam hatinya. Dzikir juga mampu mengingatkan seseorang bahwa yang membuat dan menyembuhkan penyakit hanyalah Allah swt., semata, sehingga dzikir mampu memberikan sugesti penyembuhannya. Dzikir merupakan amalan ibadah yang dapat mendatangkan pahala dan bisa menjadikan terapi untuk berbagai penyakit, baik fisik maupun psikis seperti stres, rasa khawatir, cemas, depresi dan lain sebagainya.

Dzikir yang berupa penyebutan "Asma Allah" secara berulang-ulang dan terus-menerus merupakan upaya yang dilakukan untuk memompakan energi positif dan sekaligus membendung energi negatif dalam diri manusia. Seseorang yang melakukan dzikir, harus memiliki prasangka positif terhadap Tuhan dan segala ciptaannya. Dengan cara itulah energi positif akan mudah merasuk dalam diri manusia.

Dzikir dapat mengembalikan kesadaran seseorang yang hilang, sebab aktivitas dzikir mendorong seseorang untuk mengingat, menyebut dan mereduksi kembali hal-hal yang tersembunyi dalam hatinya. Dzikir juga mampu mengingatkan seseorang bahwa yang membuat dan menyembuhkan penyakit hanyalah Allah swt.,. semata, sehingga dzikir mampu memberi sugesti penyembuhannya.

Disinilah pentingnya berdzikir dalam membentuk kepribadian manusia. Dengan selalu berdzikir kepada Allah, hati akan selalu mendapat "makanan". Hati akan berfungsi sebagai alat kontrol bagi perilaku manusia secara baik. Dengan dzikir manusia akan sejahtera jiwanya, sehingga sejahtera pula tingkah laku individu dan sosialnya. Mereka akan mampu menerima kenyataan yang ada, dan dapat meletakkan hakekat kemanusiaan yang betul-betul insani. ${ }^{32}$ Allah swt. berfirman dalam QS. Al-Baqarah/2:152.

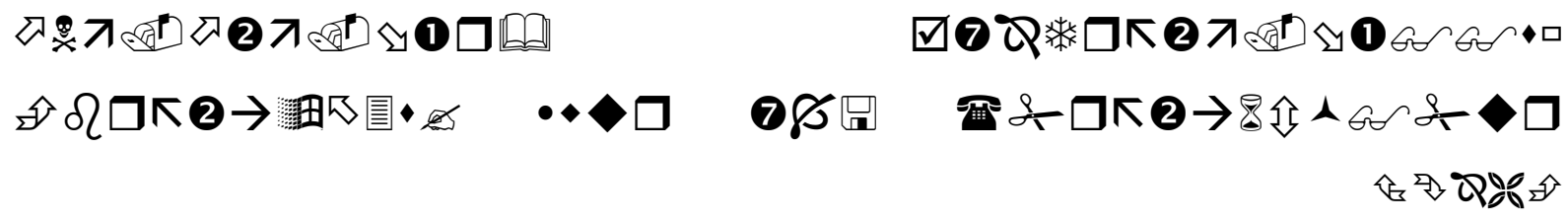

Terjemahnya :

${ }^{31}$ Gusti Abdurrahman, Terapi Sufistik untuk Penyembuhan Gangguan Kejiwaan (Yogyakarta: Aswaja Pressindo, 2010), 77.

${ }^{32}$ Afif Ansori, Dzikir Demi Kedamaian Jiwa, (Yogyakarta: Pustaka Pelajar, 2003) h.79. 
Karena itu, ingatlah kamu kepada-ku niscaya Aku ingat (pula) kepadamu, dan bersukurlah kepada-ku, dan janganlah kamu mengingkari (Nikmat)-ku. ${ }^{33}$

c. Terapi Al-Qur'an

Al-Quran sebagai sarana pengobatan sudah termasyhur di kalangan orang Islam, diantara nama-nama lain dari Surah al-Fatihah adalah al-Shifa' dan al-Ruqyah. ${ }^{34}$ Kalimat Allah, yaitu ayat-ayat Al Qur'an, mengandung tenaga tak terhingga, tenaga nuklir pun belum apa-apa dibandingkan dengan tenaga llahi ini. Kebesaran dari pada Kalimat-kalimat Allah itu, untuk menyambut dan menghancurkan sekaligus, akan ancaman-ancaman bahaya maut bagi umat manusia seperti tersebut di atas! Kalau bukit-bukit dapat dilebur oleh ayat Al Hasyr: 21, dan kalau bukit-bukit dapat dibelah dengan ayat Ar Ra'du: 31, pasti apa saja bisa dilebur oleh Kalimah-kalimah Allah yang Maha Agung, termasuk senjata-senjata atom dan nuklir dari negara-negara super power, sehingga bahaya 'kalimat' yang didatangkan oleh tenaga atom dan nuklir dapat dimusnahkan sama sekali...". ${ }^{35}$, juga Al Quranul Karim dan Kalimah Allah dapat menghancurkan segala macam penyakit yang berat-berat termasuk kanker dan AIDS sesuai dengan QS. Al Israa'/17: 82

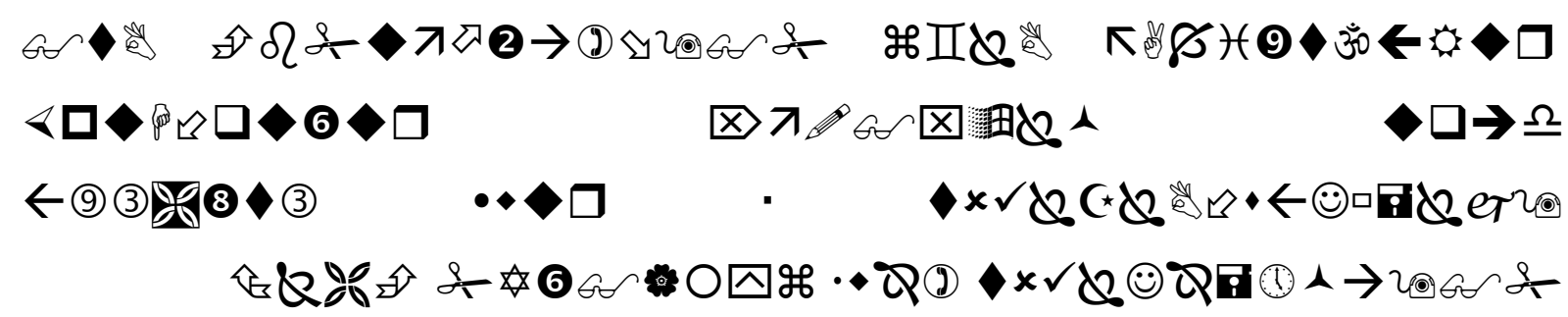

Terjemahnya:

Dan Kami turunkan dari Al Quran suatu yang menjadi penawar dan rahmat bagi orang-orang yang beriman dan Al Quran itu tidaklah menambah kepada orang-orang yang zalim selain kerugian. ${ }^{36}$

Praktek menggunakan ayat al-Quran untuk menyembuhkan berbagai macam penyakit juga dilakukan oleh Muhammad Zuhri, seorang guru sufi, dia bertindak sebagai konselor sebuah yayasan "Barzakh Fondation" yang berlokasi di Jakarta, sebuah yayasan non profit yang memberikan pelayanan gratis terhadap pengidap HIV/AIDS, kanker, sakit jiwa, luekemia, impontensi dan lain-lain. Terkadang pasien diberikan wifiq (potongan kertas yang berisi ayat-ayat Quran) dengan disertai tata cara penggunaannya.

Ayat Al-Qur'an sebagai bentuk lahiriah Al-Qur'an, ditulis dengan huruf Arab, dimana huruf ini bisa sebagai penyembuhan penyakit, dengan cara menulis huruf Al-Qur'an di dalam secarik kertas dan

\footnotetext{
${ }^{33}$ Kementerian Agama RI, Al-Qur'an dan Terjemahnya., h. 23.

${ }^{34}$ Al-Qurtubi, al-Jami li Ahkam al-Quran (Beirut: Al-Resalah, 2006), h. 184.

${ }^{35}$ Martin Van Bruinessen, Tarekat Naqsabandiyah di Indonesia, (Bandung: Mizan, 1996), h. 155-156.

${ }^{36}$ Kementerian Agama RI, Al-Qur'an dan Terjemabnya., h. 290.
} 
disuarakan dengan do'a bisa ditempelkan pada tubuh yang sakit, atau ayat Al-Qur'an ditulis pada gelas lalu dihilangkan dengan air, airnya diminum sebagai obat. ${ }^{37}$

Membaca Al-Qur'an, terlebih menghafalkannya, diyakini para ilmuan dunia mampu membuat kita sehat dan berdampak positif terhadap kejiwaan, psikis, intelektual, spiritual, dan jasmani seseorang. Membaca Al-Qur'an dapat membuat kita makin sehat, sebagaimana vitamin yang baik bagi tubuh. Hal ini sesuai dengan salah satu manfaat Al-Qur'an yang berfungsi sebagai syifa', yang berarti penyembuhan atau obat. ${ }^{38}$

Ayat-ayat Al-Qur'an mengandung aplikasi terapi sufistik untuk orang-orang yang ummi, buta huruf, tidak dapat menulis dan tidak dapat membaca, atau orang-orang yang picik dari wawasan keIslaman, dan orang-orang yang telah terjebak dalam ruang lingkup fanatisme sektarian. Oleh karena itulah mereka sangat mudah terganggu jiwanya. Mereka tidak memiliki pedoman bagaimana cara membangun dan mengembangkan kepribadian yang qur'ani. Bagaimana cara mengembangkan, berfikir, berperasaan, perilaku melakukan interaksi vertikal dan horisontal yang qur'ani dan sebagainya. $^{39}$

Al-Qur'an adalah obat yang paling utama dalam kedokteran jiwa, santapan dan kenikmatan rohani, cahaya hati dan penerang kegelapan. Al-Qur'an juga merupakan suatu yang menggembirakan mata dan cahaya penglihatan, serta kesembuhan bagi tubuh dan jiwa. ${ }^{40}$

Al-Qur'an sebagai terapi gangguan kejiwaan, sebab didalamnya memuat resep-resep mujarab yang dapat menyembuhkan penyakit jiwa manusia. Tingkat kemujarabannya sangat tergantung seberapa jauh tingkat sugesti keimanan pasien. Sugesti yang dimaksud dapat diraih dengan mendengar dan membaca, memahami dan merenungkan, serta melaksanakan isi kandungannya.

Fungsi dan tujuan yang lain dari pembacaan ayat-ayat al-Qur'an salah satunya sebagai tindakan pengobatan atau penyembuhan terhadap penyakit kejiwaan (mental), bahkan dapat juga untuk penyakit spiritual dan fisik.

Membaca al-Qur'an seutuhnya secara tartil (sebagai amalan dan wirid) atau dengan memahami makna melalui tafsir dan ta'wilnya akan menghasilkan potensi pencegahan, perlindungan dan penyembuhan terhadap penyakit psikologis secara umum. Artinya, segala bentuk atau sesuatu apapun yang menjadi penyebab terganggunya eksisitensi kejiwaan (mental) akan dapat hilang, lenyap, dan bahkan menyehatkan kejiwaan (mental), spiritual maupun fisik, apabila metode, cara dan tekhnik membaca, memahami dan mengamalkannya dengan penuh keyakinan yang mantap, disiplin dan

\footnotetext{
${ }^{37}$ Hakim Mu'inuddin Chisyti, h. 162

${ }^{38}$ M. Sanusi, Berbagai Terapi Kesehatan melalui Amalan-amalan Ibadah (Jogjakarta: Najah, 2012), 157.

${ }^{39}$ Hamdani Bakran, h. 403

${ }^{40}$ Muhammad Mahmud, Do'a sebagai Penyembuh, (Bandung: Al-Bayan, 1998), h. 95.
} 
berulang-ulang atau telah memenuhi prinsip-prinsip (syarat-syarat) membaca al-Qur'an secara tartil sebagai amalan dan wirid yang dapat menghasilkan potensi prefentif, protektif dan terapis.

Prinsip-prinsip membaca al-Qur'an adalah sebagai berikut:

1) Niat, i'tikad, tujuan dan maksud yang lurus dan suci.

Niat dalam hati adalah mengharap ridhla, cinta perjumpaan dengan Allah. I'tikadnya adalah menyakini sedalam-dalamnya bahwa Allah pasti akan meridhlai, mencintai dan berkenan untuk dijumpai, serta menyakinai bahwa Allah jugalah sesungguhnya Dzat yang Maha Memberi Kesembuhan dan Kesehatan. Tujuan adalah menghampiri kehadirat Allah, sedangkan maksudnya adalah memohon permohonan qudrat dan iradat-Nya agar dengan perantara membaca al-Qur'an, Allah berkenan memberikan energi dan potensi penyembuh.

2) Dalam keadaan suci lahir dan batin.

Kesucian lahir dapat dilakukan dengan jalan mensucikan yang najis (istinja'), mensucikan yang kotor (mandi) dan mensucikan yang bersih $\left(w u d h u^{\prime}\right)$. Sedangkan kesucian batin dapat dilakukan shalat taubat dan memperbanyak membaca istighfar.

3) Shalat Hajat dua raka'at.

Shalat hajat ini merupakan tempat yang paling patut bagi seorang hamba untuk memohon pertolongan Allah, dan sekaligus sebagai sikap sopan-santun dan rasa tawadhu' hamba kepada Allah.

4) Setelah mendirikan shalat hajat, membaca istighfar.

Membaca shalawat kepada Nabi Muhammad SAW.

5) Membaca Isti'adzah dan Basmalah.

Menjaga kedisiplinan, konsisten dan terus-menerus, seperti paling lambat satu bulan khatam atau satu minggu khatam. Membaca doa khatam Qur'an. Esensi dari doa itu apabila sering diulangulang setelah khatam (tamat) membaca Qur'an sebanyak $30 \mathrm{juz}$ adalah mengandung potensi prefentif, proteksi dan terapis yang sangat luar biasa.

Apabila prinsip-prinsip atau syarat-syarat tersebut dipegang teguh dalam membaca al-Qur'an secara utuh, maka akan menghasilkan potensi prefentif, protektif dan terapis, baik bagi yang membaca atau yang dibacakan.

Membacakan ayat al-Qur'an akan mempunyai fungsi dan tujuan sebagai berikut :

a) Fungsi membacakan ayat al-Qur'an

Berfungsi sebagai pencegahan (preventif) dan perlindungan (protektif) yakni sebagai permahonan (doa) agar senantiasa dapat terhindar dan terlindungi dari berbagai gangguan kejiwaan.

b) Tujuan membacakan ayat al-Qur'an 
Untuk membangkitkan pikiran, menggelorakan perasaan, menggugah kesadaran, dan menajamkan wawasan dan memberikan penyembuhan atau pengobatan tehadap penyakit gangguan kejiwaan bahkan dapat juga untuk penyakit spiritual dan fisik.

\section{d. Doa}

Doa dapat diartikan sebagai permintaan atau permohonan. Sedangkan secara istilah doa berarti penyerahan kepada Allah SWT dalam memohon segala yang diinginkan dan meminta dihindarkan segala yang dibenci. Doa bisa diartikan sebagai amalan ibadah mahdah, yakni ibadah yang langsung berhubungan vertikal kepada Allah.

Sebagai terapi, doa merupakan sebuah terapi yang luar biasa. Banyak orang yang sembuh penyakitnya hanya dengan beberapa ucapan doa dari orang-orang tertentu. Dadang Hawari, dalam bukunya "Dimensi Religi dalam Praktik Psikiatri dan Psikologi", mengoleksi banyak hasil penelitian dari para ahli mengenai doa sebagai "obat". Para peneliti itu antara lain: Mattews dari Universitas Georgetown, Amerika Serikat, yang menyatakan bahwa dari 212 penelitian yang telah dilakukan para ahli sebelumnya, ternyata $75 \%$ menyimpulkan adanya pengaruh positif pada pasien, dan hanya $7 \%$ yang menyatakan pengaruh negatif doa terhadap hasil terapi. Manfaat doa terhadap proses kesembuhan pasien terutama terletak pada berbagai penyakit, seperti depresi, kanker, hipertensi, jantung dan penyalahgunaan NAZA (Narkotika, Alkohol, dan Zat Adiftif).

e. Shalat

Shalat membersihkan seorang muslim dari kotoran dan mikroba atau segala sesuatu yang dapat membuatnya sakit, baik yang nampak maupun tidak, sebagaimana orang yang mandi di sungai lima kali sehari. Shalat dapat menghapuskan dosa yang dikerjakan diantara waktu shalat tersebut dan waktu shalat berikutnya, selama tidak mengerjakan dosa-dosa besar.

Shalat dapat menghilangkan ketegangan karena adanya perubahan pola gerak tubuh. Sebagaimana diketahui, gerak seperti ini, secara fisiologi akan menimbulkan nuansa rehat yang penting bagi tubuh. Rasulullah SAW telah mengingatkan kaum muslimin agar mewaspadai sifat amarah dalam hal ini, shalat mempunyai pengaruh langsung bagi susunan saraf, di mana ia dapat menenangkan gejolaknya dan menjaganya agar tetap tenang. Sebagaimana shalat juga menjadi obat mujarab bagi insomnia yang diakibatkan oleh gangguan saraf. ${ }^{41}$

Terminologi shalat mengisyaratkan bahwa di dalamnya terkandung adanya hubungan antara manusia dengan Tuhannya. Di dalam shalat, manusia berdiri dengan khusuk dan tunduk kepada

\footnotetext{
${ }^{41}$ Manshur Abdul Hakim Muhammad, Berobat dengan Shalat; Menemukan Keajaiban Shalat untuk Kesehatan Fisik dan Mental (Solo: Al-Hambra, 2011), 33.
} 
Allah swt, pencipta-Nya dan pencipta seluruh alam semesta. Dengan tubuhnya yang kecil dan lemah ia berdiri di hadapan Tuhan Yang Maha Agung. Berdirinya manusia dihadapan Allah dengan khusyuk dan tunduk akan membekalinya dengan suatu tenaga rohani yang timbul dalam diri perasaan yang tenang, jiwa yang damai dan kalbu yang tentram, sebab dalam shalat yang dilakukan dengan semestinya, manusia mengarahkan seluruh jiwa dan raganya kepada Allah, berpaling dari semua kesibukan dan problem dunia, dan tidak memikirkan sesuatu kecuali Allah dan ayat-ayat al-Qur'an yang dibacanya. ${ }^{42}$

Keadaan yang tenang dan jiwa yang damai ditimbulkan shalat juga membantu melepaskan diri dari kegelisahan yang dikeluhkan oleh para pasien gangguan jiwa. Keadaan tenang dan jiwa damai yang ditimbulkan shalat biasanya tetap berlangsung untuk beberapa lama setelah shalat selesai.

Setidaknya ada empat aspek terapeutik yang terdapat pada aktifitas shalat, yakni aspek olah raga, meditasi, auto-sugesti dan aspek kebersamaan.

Pertama, aspek olah raga karena shalat menuntut aktifitas fisik, dimana reaksi otot, tekana dan message merupakan aspek relaksasi, dimana proses ini biasa dipergunakan terapi untuk mengurangi ketegangan dan kecemasan.

Kedua, aspek meditasi yang dimaksud adalah konsentrasi (khusyuk) yang dituntut dalam melakukan shalat, sehingga pikiran hanya tertuju pada Tuhan. Dengan demikian maka pikiran akan menjadi cerah dan ringan dari beban kecemasan.

Ketiga, aspek auto-sugesti dimana pada bacaan shalat yang ditujukan kepada Allah disamping berisi pujian juga mengandung doa agar selamat di dunia dan akhirat. Bila ditinjau dari teori hipnotis yang merupakan salah satu metode terapi kejiwaan, maka pengucapan kata-kata itu merupakan suatu proses auto-sugesti, mengatakan hal-hal yang baik pada diri sendiri adalah mensugesti dirinya agar memiliki sifat yang baik, demikian juga akan memunculkan harapan yang positif dan optimis.

Keempat, aspek kebersamaan yang terdapat dalam shalat berjama'ah juga mempunyai dampak terapeutik yang signifikan, yaitu membantu dan berinteraksi dengan orang lain sebagai upaya menciptakan hubungan sosial yang sehat dan hubungan persahabatan antar mereka. Pada akhir-akhir ini berkembang terapi kelompok dimana tujuan utamanya adalah menimbulkan suasana kebersamaan. Sebagaimana pendapat banyak psikologi, bahwa "ketersaingan" dari orang lain adalah penyebab terjadinya gangguan kejiwaan. ${ }^{43}$ Ini disebabkan karena seringnya seseorang pergi ke masjid untuk menjalankan shalat berjamaah dan memiliki kesempatan untuk mengenal tetangganya atau orang lain.

\footnotetext{
${ }^{42}$ Ustman Najati, Al-Qur'an dan Ilmu Jiwa, terjemahan: Ahmad Rofi' Usmani, (Bandung: Pustaka, 1985), h. $307-308$ 100.

${ }^{43}$ Djamaluddin Ancok dan Fuat Nashori, Psikologi Islami, (Yogyakarta: Pustaka Pelajar, 1995), h. 98-
} 
Hubungan yang demikian ini akan membantu seseorang mengembangkan kepribadian dan kematangan emosionalnya.

Hazrat Inayat Khan telah mengatakan, "seorang yang tidak pernah melaksanakan shalat tidaklah memiliki harapan akan perkembangan jalan-jalan yang lainnya, karena setiap postur dalam shalat memiliki suatu makna yang indah dan pengaruh tertentu. Shalat ini diperintahkan sebelum meneruskan pengajaran sakral berikutnya. Jika ia gagal mengembangkannya, maka tidak ada harapan baginya akan masa depan".

Shalat dikerjakan dengan melakukan posisi tubuh yang berbeda-beda dan membaca beberapa ayat al-Qur'an pada setiap postur dan pada postur-postur ini akan diberikan penjelasan mengenai manfaatnya masing-masing.

Postur Pertama, yaitu postur niat/takbiratul ihram. Pada postur ini kita mengangkat kedua tangan terbuka keatas sampai telinga, dan letakkan ibu jari dibawah daun telinga sambil mengucapkan Allahu Akbar. Pengaruh-pengaruh yang menguntungkan yaitu tubuh terasa ringan karena berat badan terbagi pada kedua kaki. Luruskan bagian punggung untuk memperbaiki postur. Pikiran berada dalam keadaan terkendali. Pandangan lurus dengan berpusat pada lantai tempat kepala menyentuh permukaan lantai. Otot-otot punggung sebelah atas dan sebelah bawah dalam keadaan kendur, pusat otak atas dan bawah menyatu untuk membentuk kesatuan tujuan.

Postur Kedua, yaitu postur Qiyam. Kita meletakkan tangan dibawah pusar, tangan kanan berada diatas tangan kiri kemudian membaca surat al- Fathihah dan surat Qur'an lainnya. Pengaruhpengaruh yang menguntungkan dalam postur ini yaitu; konsentrasi penuh, menyebabkan relaksasi pada kaki dan punggung menggerakkan perasaan rendah hati, kesederhanaan dan ketaatan. Pada pembacaan ayat diatas, seluruh bunyi diucapkan dalam bahasa Arab, yang akan memacu penyebaran seluruh sifat-sifat Allah yang Agung akan derajat yang terkendali secara sempurna di seluruh tubuh, pikiran dan jiwa. Getaran suara vokal panjang a, i dan u akan memacu hati, kelenjar pireal, kelenjar pituitary, kelenjar adreanalin dan paru-paru, serta akan membersihkan dan meningkatkan fungsi seluruh bagian itu. ${ }^{44}$

Postur ketiga, yaitu postur Ruku'. Pengaruh pengaruh yang menguntungkan; merenggangkan otot-otot punggung sebelah bawah, otot paha serta otot betis secara penuh. Darah akan terpompa keatas tubuh. Menekan otot lambung, perut dan ginjal. Postur ini akan meningkatkan kepribadian, menggerakkan kasih sayang dan keharmonisan pada bagian sebelah dalam. Postur ini menjaga kesempurnaan posisi dan fungsi tulang belakang (corpus vertebrae) sebagai penyangga tubuh dan pusat syaraf. Posisi jantung sejajar dengan otak, maka aliran darah maksimal pada tubuh bagian

\footnotetext{
${ }^{44}$ Sagiran. Mukjizat Gerakan Shalat., h. 39
} 
tengah. Tangan yang bertumpu di lutut berfungsi relaksasi bagi otot-otot bahu hingga ke bawah. Selain itu, rukuk adalah latihan kemih untuk mencegah gangguan prostat.

Postur keempat, yaitu postur Qauna/I'tidal. Postur: Bangun dari rukuk, tubuh kembali tegak setelah, mengangkat kedua tangan setinggi telinga. Manfaat: I'tidal adalah variasi postur setelah rukuk dan sebelum sujud. Gerak berdiri bungkuk berdiri sujud merupakan latihan pencernaan yang baik. Organ organ pencernaan di dalam perut mengalami pemijatan dan pelonggaran secara bergantian. Efeknya, pencernaan menjadi lebih lancar. Efek yang lain adalah; darah yang segar tergerak keatas kedalam tubuh pada postur sebelumnya kembali pada keadaannya semula, yang akan mengeluarkan toksin, tubuh akan mengalami relaksasi dan melepaskan semua ketegangan. ${ }^{45}$

Postur kelima, yaitu postur Sujud. Pengaruh-pengaruh yang menguntungkan adalah; lutut yang membentuk sudut yang tepat akan memungkinkan otot-otot lambung berkembang dan mencegah timbulnya kekenduran pada sekat rongga badan. Meningkatkan aliran darah kedalam bagian tubuh sebelah atas, terutama kepala (termasuk mata, telinga, dan hidung) dan paru-paru, memungkinkan toksin-toksin dagu dapat dibersihkan oleh darah. Mempertahankan posisi tetus yang tepat pada wanita yang sedang hamil. Mengurangi tekanan darah yang tinggi, meningkatkan aktifitas persendian, menghilangkan egoisme dan kesombongan. Meningkatkan kesabaran dan keyakinan kepada Allah swt., meningkatkan tahap perhatian spiritual dan menghasilkan energi psikis yang tinggi di seluruh tubuh. Postur penyerahan dan kemurahan hati yang tinggi ini merupakan esensi ibadah. Postur ini juga menghindarkan gangguan wasir. Khusus bagi wanita, baik rukuk maupun sujud memiliki manfaat luar biasa bagi kesuburan dan kesehatan organ kewanitaan. ${ }^{46}$

Postur keenam, adalah Qu'ud/duduk. Postur: Duduk ada dua macam, yaitu iftirosy (tahiyyat awal) dan tawarruk (tahiyyat akhir). Perbedaan terletak pada posisi telapak kaki. Manfaat: Saat iftirosy, kita bertumpu pada pangkal paha yang terhubung dengan syaraf nervus Ischiadius. Posisi ini menghindarkan nyeri pada pangkal paha yang sering menyebabkan penderitanya tak mampu berjalan. Duduk tawarruk sangat baik bagi pria sebab tumit menekan aliran kandung kemih (urethra), kelenjar kelamin pria (prostat) dan saluran vas deferens. Jika dilakukan dengan benar, postur ini mencegah impotensi. Variasi posisi telapak kaki pada iffirosy dan tawarruk menyebabkan seluruh otot tungkai turut meregang dan kemudian relaks kembali. Gerak dan tekanan harmonis inilah yang menjaga kelenturan dan kekuatan organ-organ gerak kita. Pengaruh-pengaruh yang menguntungkan juga adalah; bagi laki-laki tumit kaki kanan mengerut dan berat kaki serta bagian tubuh berada pada tumit tersebut. Posisi ini membantu pengeluaran zat racun dari liver dan memacu gerak peristaltik pada

\footnotetext{
${ }^{45}$ Sagiran. Mukjizat Gerakan Shalat., h. 40.

${ }^{46}$ Sagiran. Mukjizat Gerakan Shalat., h. 40.
} 
usus besar. Bagi perempuan pertahankan kedua kaki di bawah badannya, telapak kaki menghadap keatas, tubuh akan kembali mengalami relaksasi yang sama, dan postur ini membantu pencernaan dengan menggerakkan isi perut kearah bawah. ${ }^{47}$

Dr. Alexis Carel, pemenang hadiah Nobel bidang kedokteran dan direktur riset pada Rockefeller Foundation Amerika mengatakan bahwasanya selama ia menjadi seorang dokter, ia melihat banyak pasien yang gagal disembuhkan secara medis, tiba-tiba penyakit itu hilang setelah mereka melakukan shalat. Shalat merupakan meditasi suci yang pelakunya merasakan kehadiran Allah swt., seperti merasakan panasnya cahaya matahari. Banyak pasiennya yang berpenyakit tuberculosis, radang tulang, luka yang membusuk dan sebagainya, bisa sembuh dengan shalat. ${ }^{48}$

f. Zakat

Zakat berasal dari bahasa Arab yaitu zaka-zaka'an-zukuwan-zakiyyah-zakat yang berarti suci, memberikan harta yang bertujuan untuk mensucikannya, sesuatu yang meliputi segala kebaikan (menambah kebaikan-kebaikan dan karunia), yaitu suci dari dosa. Menurut terminologi, zakat berarti sejumlah harta yang wajib dikeluarkan dan diberikan kepada orang yang berhak menerimanya dan bila mencapai nisab tertentu, dan dengan syarat-syarat tertentu pula. ${ }^{49}$

Zakat merupakan metodologi membersihkan diri dengan cara mengeluarkan dan memberikan harta kepada orang yang berhak menerimanya. Bagi umat Islam zakat merupakan kewajiban baginya dan zakat merupakan rukun Islam yang keempat.

Zakat merupakan metode membersihkan diri dengan cara mengeluarkan dan memberikan harta kepada orang yang berhak menerimanya. Melalui metode zakat kita juga dapat melakukan perawatan rohani Islam yang kita lakukan dengan menyandarkannya pada kemutlakkan tuhan dan upaya maksimal manusia dengan menggunakan metode-metode yang membantu dalam sisi terapi spitualitas dan psikis manusia. ${ }^{50}$

Zakat membuat seseorang mencintai orang lain, terhindar dari sifat egios, kikir dan lain sebagainya. Kemampuan seseorang untuk mencintai orang lain, berbuat baik pada mereka dan berusaha membuat mereka bahagia, akan memperkuat perasaan keanggotaan kelompoknya, dan membuatnya merasa berperan aktif berguna dalam masyarakat, sehingga membuatnya merasa puas terhadap dirinya sendiri. Perasaan demikian sangat besar pengaruhnya terhadap kesehatan jiwa seseorang. Al-Qur'an telah berbicara mengenai sadaqah, baik berupa zakat maupun sunnah, bahwa ia

\footnotetext{
${ }^{47}$ Sagiran. Mukjizat Gerakan Shalat., h. 41.

${ }^{48}$ Moh. Ali Aziz. 60 Menit Terapi Shalat Bahagia. (Surabaya: IAIN Sunan Ampel Press, 12), 191.

${ }^{49}$ Wahbah Al-Zuhayly, Zakat Kajian Berbagai Mazhab, (Bandung: PT. Remaja Rosdakarya, 1997), h. 82.

${ }^{50}$ Khairunnas Rajab, Psikologi Ibadah: Memakmurkan Kerajaan Ilahi di Hati Manusia, (Jakarta: Bumi Aksara, 2006 ), h. 101.
} 
membersihkan diri dan mensucikan jiwa manusia, ${ }^{51}$ sebagaimana firman-Allah swt., dalam QS. Attaubah/9:103

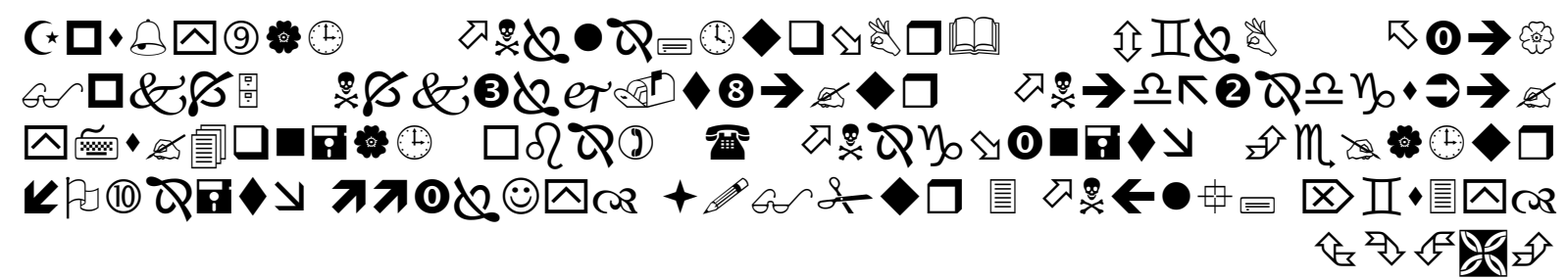

Terjemahnya:

Ambillah zakat dari harta mereka, guna membersihkan dan menyucikan mereka, dan berdoalah untuk mereka. Sungguh doa-mu itu (menumbuhkan) ketentraman jiwa bagi mereka. Allah Maha Mendengar lagi Maha Mengetahui. ${ }^{52}$

Maksud dari ayat diatas adalah dengan zakat itu mereka menjadi bersih dari kekikiran dan dari berlebih-lebihan dalam mencintai harta benda atau zakat itu akan menyucikan orang yang mengeluarkannya dan akan menumbuhkan pahalanya.

Zakat mempunya makna dan tujuan secara vital, teruma sebagai cobaan dari kecintaan kepada Allah selaku pemilik dan penguasa harta kekayaan dan nikmat yang telah dianugrahkan kepada Muzakki. Zakat adalah metodelogi dalam membersihkan diri dari sifat bakhil dan melahirkan rasa syukur yang dalam terhadap limpahan anugerah dan rahmat oleh Allah, Rabb al-'alamin. Allah memerintahkan agar umat Islam menunaikan kewajiban zakat, sebagai cobaan dan bukti kecintaan seorang muslim terhadap sesama dan kepada Allah swt. ${ }^{53}$

Zakiah Daradjat dalam bukunya yang berjudul "Zakat Pembersih Harta dan Jiwa" (1992) yang membahas hubungan zakat dengan kesehatan mental, disertai contoh yang terjadi dalam kehidupan nyata. Di dalam buku itu Zakiah Daradjat mengajak pembaca memetik hikmah, seorang perempuan kaya diusia tuanya mengeluh kesehatannya terganggu. Selera makan hilang dan tidur tidak nyenyak. Dia telah berobat kepada beberapa dokter spesialis, namun tidak sembuh. Hampir tiap hari merasa penyakitnya bertambah berat. Seorang temannya berkata: "Barangkali Anda tidak menunaikan zakat." Tentu saja ditangkisnya tuduhan itu. Dia merasa telah mengeluarkan zakat, hampir setiap hari dia berzakat. Namun dalam hati kecilnya timbul kegelisahan. Untuk menghilangkan kegelisahan, dia datang ke tempat praktik konsultasi Zakiah Daradjat. Terjadilah dialog sebagai berikut: "Benarkah penyakit saya ini disebabkan karena tidak berzakat?", tanyanya. "Mengapa Anda bertanya demikian?" Belakangan ini saya sering sakit. Macam-

\footnotetext{
${ }^{51}$ Muhammad Usman, Al-Qur'an dan Psikologi, (Jakarta: Tb Asnawi Syihabuddin, 2005), h. 239.

${ }^{52}$ Kementerian Agama RI, Al-Qur'an dan Terjemahnya, h. 203.

${ }^{53}$ Imam al-Ghazali, Ihya Ulumiddin I: al-Qahirah: Muassasah al-Halabi wa Syirkah Li al-Nasriwa Tauziog, h. 296.
} 
macam penyakit yang datang. Obat yang diberikan dokter, tidak ada yang menolong. Saya ceritakan kepada teman, justru saya dikatakannya tidak menunaikan zakat, padahal saya selalu berzakat. Setiap ada orang minta sumbangan, selalu saya beri."

"Bagaimana Anda menentukan berapa zakat yang wajib Anda keluarkan?" Yah, itu tidak saya hitung, yang jelas hampir setiap hari saya mengeluarkan uang sepuluh ribu rupiah, kadang-kadang lebih." Yang Anda berikan kepada orang miskin atau peminta sumbangan dengan cara seperti itu, bukanlah zakat, akan tetapi shadaqah atau sumbangan sukarela. Anda berpahala dengan shadaqah atau sumbangan seperti itu. Akan tetapi, kewajiban Anda untuk mengeluarkan zakat dengan cara demikian, belum terlaksana." Wanita itu terdiam. Ia tersentak dan menyesali dirinya. Mengapa selama ini tidak menanyakan kepada orang yang mengerti masalah zakat.

Menurut Zakiah Daradjat, pada dasarnya harta memang menunjang kehidupan manusia. Sebaliknya, harta dapat berubah menjadi penyebab kegelisahan, perselisihan dan permusuhan. Karena harta, orang berkelahi. Karena harta, hubungan persaudaraan menjadi renggang, bahkan karena harta, hubungan keluarga menjadi putus. Tidak jarang, perselisihan anak dan orang tua terjadi disebabkan harta. Sebetulnya, bukan harta yang menjadi penyebab. Sebabnya mungkin cara mendapatkan harta itu yang tidak benar, atau sebagian kecil dari harta itu yang sesungguhnya milik orang lain, tidak dikeluarkan."

Disinilah peranan zakat. Manfaat zakat bagi penerimanya sudah jelas, membantunya dalam memenuhi keperluan hidup yang tidak dapat dipenuhinya sendiri. Sedangkan manfaat zakat bagi yang menunaikannya cukup banyak, terutama dalam menjadikan hidup bersih dan sehat. Boleh jadi orang tidak pernah menyangka bahwa zakat mempunyai pengaruh terhadap kesehatan, baik jasmani maupun rohani. Memang ada sementara orang yang menjadi kaya atau banyak harta, menjauh dari orang miskin dan kurang perhatian kepada kegiatan sosial kemasyarakatan. Ia terasing dari lingkungannya. ${ }^{54}$

Melalui metode zakat, maka perawatan rohani yang kita dapatkan ialah:

- Mendatangkan kebahagiaan batin

- Implementasi kepada peningkatan spiritual, kesehatan mental dan kepribadian Qur'ani secara realistis

- Mampu menghapus sifat bakhil yang ditukar dengan sifat dermawan

- Mensyukuri nikmat Allah sehingga dapat menyucikan diri dan mengembangkan kepribadiannya. ${ }^{55}$

${ }^{54}$ M. Fuad Nasar, Zakat Sebagai Terapi Kegelisahan Jiwa. http://www.bpsannursidoarjo.com/2013/07/zakat-sebagai-terapi-kegelisahan-jiwa.html (diakses tgl 2 10-16).

${ }^{55}$ Imam al-Ghazali, Ihya Ulumuddin I: al-Qahirah: Muassasah al-Halabi wa Syirkah Li al-Nasriwa Tauziog, h. 296. 


\section{DAFTAR PUSTAKA}

Aziz, Moh. Ali. 60 Menit Terapi Shalat Bahagia. (Surabaya: IAIN Sunan Ampel Press, 12).

Abdurrahman, Gusti. Terapi Sufistik untuk Penyembuhan Gangguan Kejiwaan (Yogyakarta: Aswaja Pressindo, 2010).

Ancok, Djamaluddin dan Fuat Nashori, Psikologi Islami, (Yogyakarta: Pustaka Pelajar, 1995).

--------. Psikologi Islam (Yogyakarta, Pustaka Pelajar, 2001), 91.

Ansori, Afif. Dzikir Demi Kedamaian Jiwa, (Yogyakarta: Pustaka Pelajar, 2003).

Bruinessen, Martin Van. Tarekat Naqsabandiyah di Indonesia, (Bandung: Mizan, 1996).

Burhani, Ahmad Najib. Manusia Modern Mendamba Allah, Renungan Tasawuf Positif, (Jakarta : Mizan Media Utama, 2002).

Chaplin, J. P. Kamus Lengkap Psikologi (Jakarta: PT. Raja Grafindo Persada, 1999).

Adz-Dzaky, Hamdani Bakran. Konseling dan Psikoterapi Islam, (Yogyakarta: Fajar Pustaka Baru, 2002).

Daradjat, Zakiah. Peranan Agama dalam Kesehatan, (Jakarta : Gunung Agung, 1982).

Fahmi, Musthafa. Penyesuaian Diri, (Jakarta : Bulan Bintang, 1997).

al-Ghazali, Imam. Ihya Ulumiddin I: al-Qahirah: Muassasah al-Halabi wa Syirkah Li al-Nasriwa Tauziog.

Jalaluddin, Psikologi Agama, Edisi Revisi, (Jakarta : PT. Raja Grafindo Persada, 2000).

Kemeterian Agama RI, Al-Qur'an dan Terjemahnya (DKU print, 2015).

Kartono, Kartini. Hygiene Mental, (Bandung: Mandar Maju, 2000). Psikologi Abnormal dan Abnormalitas Seksual, (Bandung: Mandar Maju, 1989).

Mahmud, Muhammad. Do'a sebagai Penyembuh, (Bandung: Al-Bayan, 1998).

Maslim, Rusdi. PPDGJ-III (Jakarta: PT. Nuh Jaya, 2001).

Muhammad, Manshur Abdul Hakim. Berobat dengan Shalat; Menemukan Keajaiban Shalat untuk Kesehatan Fisik dan Mental (Solo: Al-Hambra, 2011).

Najati, Ustman. Al-Qur'an dan Ilmu Jiwa, terjemahan: Ahmad Rofi' Usmani, (Bandung: Pustaka, 1985).

An-Najar, Amir. Psikoterapi Sufistik dalam Kehidupan Modern. ter. Ija Suntana (Jakarta: Mizan Publika, 2004).

Nasar, M. Fuad Zakat Sebagai Terapi Kegelisahan Jiwa. http://www.bpsannursidoarjo.com/2013/07/zakat-sebagai-terapi-kegelisahan-jiwa.html (diakses tgl 2 10-16).

Al-Qurtubi, al-Jami li Ahkam al-Quran (Beirut: Al-Resalah, 2006).

Rajab, Khairunnas. Psikologi Ibadah: Memakmurkan Kerajaan Ilahi di Hati Manusia, (Jakarta: Bumi Aksara, 2006 ).

Sagiran. Mukjizat Gerakan Shalat. 
Sanusi, M. Berbagai Terapi Kesehatan melalui Amalan-amalan Ibadah (Jogjakarta: Najah, 2012).

Shihab, M. Quraish Tafsir Al-Mishbah, Volume: 6 (Jakarta: Lentera Hati, 2002).

Solihin, M. Penyembuhan Penyakit kejiwaan Perspektif Tasawuf (Bandung: Pustaka Setia, 2004).

Terapi Sufistik; Penyembuhan Penyakit Kejiwaan Perspektif Tasawuf (Bandung: Pustaka Setia, 2004).

Syukur, M. Amin Sufi Healing; Terapi dengan Metode Tasawuf (Jakarta: Erlangga, 2012).

Usman, Muhammad. Al-Qur'an dan Psikologi, (Jakarta: Tb Asnawi Syihabuddin, 2005).

Wirawan, Sarwono Sarlito. Pengantar Umum Psikologi, (Jakarta: Bulan Bintang, 1996).

Al-Zuhayly, Wahbah. Zakat Kajian Berbagai Mazhab, (Bandung: PT. Remaja Rosdakarya, 1997). 